\title{
Attention-Deficit/Hyperactivity Disorder
}

A Current Overview

Tobias Banaschewski, Katja Becker, Manfred Döpfner, Martin Holtmann, Michael Rösler, Marcel Romanos

\section{SUMMARY}

Background: Attention-deficit/hyperactivity disorder (ADHD) is a common, early-onset, persistent developmental disorder of childhood and adolescence, with a prevalence of approximately $5 \%$.

Methods: This article is based on publications retrieved by a selective search in PubMed with an emphasis on pertinent guidelines and systematic reviews.

Results: At least $75 \%$ of affected children and adolescents develop a comorbid disorder, which impedes diagnosis and treatment and worsens prognosis. The etiology of ADHD is complex and heterogeneous, involving a major genetic component and diverse neurobiological alterations. Prenatal environmental factors also seem to elevate the risk of ADHD. The mainstays of treatment are psychoeducation, behavioral therapy, and psychoactive drugs, which generally have only mild side effects, such as insomnia or decreased appetite. The indication for treatment in the individual case is based on severity, comorbidity, previous therapy attempts, and the familial, social, and educational framework conditions.

Conclusion: Translational research is needed to clarify the etiology of ADHD. Epidemiological studies published since 1987 do not reveal any increase in the prevalence of ADHD among children and adolescents. Improved diagnosis necessitates an evidence-based and need-adapted approach to treatment.

\section{- Cite this as:}

Banaschewski T, Becker K, Döpfner M, Holtmann M, Rösler M, Romanos M: Attention-deficit/hyperactivity disorder-a current overview. Dtsch Arztebl Int 2017; 114: 149-59. D0l: 10.3238/arztebl.2017.0149

Central Institute of Mental Health, Medical Faculty Mannheim/Heidelberg University, Mannheim, Germany: Prof. Dr. med. Dr. rer nat. Banaschewski

Department of Child and Adolescent Psychiatry, Philipps University, Marburg: Prof. Dr. med. Becker

Department of Child and Adolescent Psychiatry and Psychotherapy, University of Cologne: Prof. Dr. sc. hum. Dipl. Psych. Döpfner

LWL University Hospital Hamm, Department of Child and Adolescent Psychiatry, Ruhr University Bochum: Prof. Dr. med. Holtmann

Department of Forensic Psychology and Psychiatry, Saarland University: Prof. Dr. med. Rösler

Department of Child and Adolescent Psychiatry, Psychosomatics and Psychotherapy, Universitätsklinikum Würzburg: Prof. Dr. med. Romanos

\begin{abstract}
1 ttention-deficit/hyperactivity disorder (ADHD; $\triangle$ according to the DSM-5) (1) and hyperkinetic disorder (HKD; according to the ICD-10) (2) describe a childhood-onset developmental disturbance that persists for at least six months and across different situations, and comprises the three core symptoms inattentiveness, impulsivity, and/or motor unrest. These core symptoms are present to an extent beyond what would be expected for the patient's age, developmental level, and intelligence. To diagnose the disorder, clinically relevant functional psychosocial impairment must be present in different settings, e.g., family, school, or work. In the general population, these core symptoms are dimensionally distributed along a continuum, the upper end of which constitutes clinically relevant ADHD symptoms (e1). In this selective review, we focus on meta-analyses, systematic reviews, large registry studies, and randomized controlled trials. The aim is to provide the reader with an evidence-based overview of the developmental trajectories in ADHD, the various and often controversial treatment options, and the current state of etiological research.
\end{abstract}

\section{Classification}

The two most commonly used nosological classification systems worldwide, the ICD-10 and the DSM-5, are broadly consistent in their operationalizations of the various symptoms of ADHD, but differ with respect to subtypes and additional criteria. The "subtypes" defined in the DSM-IV have been attenuated to "presentations" in the DSM-5, due to their temporal instability and frequent developmentally dependent changes from one category to another (e2, e3). The DSM-5 is the first classification system to define specific features of ADHD in adults, reducing the number of symptoms necessary for diagnosis from the age of 17 , due to the

\section{Core symptoms}

The core symptoms of ADHD and HKD are inattentiveness, impulsivity, and/or motor unrest. 
fact that functional impairment can persist or worsen with age despite an age-dependent reduction of symptoms (e3, e4). Moreover, the age of onset criterion has been raised to 12 in the DSM-5, as an older age of onset (between 7 and 12 years) was found to show no effect on clinical manifestation, symptom severity, nature and extent of comorbid disorders, neuropsychological findings and functional impairment, progression or treatment response (e5).

\section{Epidemiology}

ADHD as defined by the DSM-IV criteria has a worldwide epidemiological prevalence of $5.3 \%$ $[5.01 \%-5.56 \%]$ and is thus one of the most common mental illnesses in childhood and adolescence $(3, \mathrm{e} 5)$. Use of the stricter ICD-10 research criteria leads to lower prevalence estimates of approximately $1-2 \%$ (e6-e8). According to the DSM-IV criteria, around $2.5 \%$ of the general adult population suffers from ADHD (4). The higher prevalence in males is more pronounced in clinical samples $(3-4: 1)$ than in epidemiological studies $(2: 1)$. ADHD is associated with a lower socio-economic status (e9). Although the rate of diagnosis has risen markedly around the world in recent decades, currently lying at approximately $4 \%$ of children and adolescents in Germany, epidemiological studies have shown no change in the worldwide population-based prevalence of $5.3 \%$ over the last 30 years (6). Rising rates of diagnosis are thus not due to a real increase in prevalence, but rather to improved diagnosis or to an increase in functional impairment $(5,6$, e10).

\section{Developmental psychopathology}

Symptom levels vary across different areas of life and according to the extent of external demands. In this respect, situations that require attention, sitting still, and impulse control are often the first in which the symptoms are experienced as causing impairment (e.g., classroom behavior, homework, chair-circle activities, etc.). Marked motor unrest before the age of four years, however, is very hard to distinguish from a variant of normal behavior. Moreover, the novelty of a situation, a high specific motivation or expectation of a reward, and strong external behavioral control can reduce symptoms in certain situations, but not in a long-lasting manner. Thus, a lack of symptoms in a circumscribed observational situation does not automatically rule out the diagnosis. In children of elementary-school age, inattentiveness becomes increasingly evident and causes greater impairment as the external demands increase. Motor unrest often lessens from adolescence onward and is often reduced to a subjectively unpleasant inner feeling of restlessness and drive, while difficulties such as inattentiveness, deficient planning ability, and impulsivity often persist (5). In adulthood, the core symptoms of ADHD may be accompanied more prominently by symptoms of emotional dysregulation, including reduced frustration tolerance, irritability, and marked mood swings $(7,8$, e11).

Prospective longitudinal studies have shown a continuous reduction of the core symptoms over the lifespan. Generally speaking, only around $5-15 \%$ of patients continue to completely fulfill the diagnostic criteria for ADHD in adulthood, although persistent symptoms or functional impairment remain in approximately $70 \%(3$, e12); however, findings vary widely across studies due to methodological differences and other reasons. Comorbid disorders may be more prominent than ADHD itself and dominate the clinical picture. A positive family history of ADHD, unfavorable psychosocial conditions (severe early childhood deprivation, psychopathology in one or both parents), severe core symptoms, and comorbid mental illnesses (particularly conduct disorders and depressive disorders) are risk factors for an unfavorable course and for the persistence of the disorder (9, e13-e16).

ADHD is associated with psychosocial functional impairment and a markedly reduced subjective healthrelated quality of life $(10,11)$. Children with ADHD are about four times less likely than their peers to obtain a college degree, and attain a lower socio-economic status on average (12). Their relationships with parents, siblings, peers, and partners are often conflict-ridden $(10,12)$. Their risk of delinquent behavior is elevated by a factor of $2-3(12$, e17). From preschool age up to age 13, the risk of suicidal ideation is almost 6 times higher than in their peers (e18), and they show a fourfold-increased lifetime risk of suicide (13, e17, e19); the severity of ADHD is correlated with the frequency of suicidality (e19). Accident-proneness, particularly regarding road traffic accidents, is the major reason for the $50 \%$ increase in mortality seen among persons with ADHD across all age groups $(9,11)$.

Although, according to the definition of ADHD, the disorder first manifests in childhood, more recent longitudinal cohort studies suggest that symptoms can also begin (or become clinically relevant) in adulthood

\section{Epidemiology}

ADHD has a worldwide epidemiological prevalence of $5.3 \%[5.01 \%-5.56 \%]$ according to the DSM-IV criteria and is thus one of the most common mental illnesses in childhood and adolescence.

\section{Developmental psychopathology}

Prospective longitudinal studies have shown a continuous reduction of the core symptoms of ADHD as patients grow older. 
(14, e20, e21). The interpretation of these findings is currently a matter of debate (e21). One possible explanation is that protective factors prevent an early clinical manifestation of the disorder, and symptoms only become evident once the individual is subjected to the greater demands of adulthood.

\section{Developmentally dependent trajectories of comorbidity}

Approximately $75 \%$ of persons with ADHD have an additional mental disorder and around $60 \%$ have multiple comorbid mental disorders; this can adversely affect prognosis and may necessitate specific therapeutic measures (15). Circumscribed developmental disorders (motor function, language, scholastic skills), anxiety disorders, tic disorders, and oppositionaldefiant disorder emerge early in child development (16). In contrast, depressive disorders and severe conduct disorders often emerge later on, toward the end of the elementary school years and during the transition to adolescence. From adolescence onward, such disorders are often associated with substance abuse and dependence (odds ratios [OR] 1.7 and 2.5, respectively) (12) and with the development of personality disorders $(8$, e22, e23). Approximately one in four children receiving treatment for ADHD also have an affective disorder $(15,16)$, while over half of all adults with ADHD have clinical depression (2.3-fold increased risk) (12, e24). Thus, the age-dependent development of comorbid disorders often occurs in specific sequential steps (e.g., from oppositional disorders, through conduct disorder, to depression with increased suicidality), particularly as comorbid disorders constitute specific risk factors for the development of further mental disorders (16).

\section{Pathophysiology \\ Genetics}

ADHD tends to run in families. First-degree relatives have a five- to tenfold increased risk of developing ADHD (e25, e26, 17). Twin studies have revealed a high degree of heritability: $70-80 \%$ of the phenotypic variance is attributable to genetic factors, sometimes in interaction with environmental factors (epigenetic changes in gene expression due to specific environmental factors) (17). The remaining variance is explained by pre-, peri-, and postnatal environmental factors that twin siblings do not share. Shared environmental effects are of secondary importance. Metaanalyses of candidate gene studies have shown that genes encoding the receptors and transporters of the catecholaminergic and serotonergic neurotransmitter systems play a role in the etiology of the disorder (17, 18). Genome-wide association studies have revealed many other potential risk variants, and their findings suggest that some $40 \%$ of the genetically determined variance is due to common variants (i.e., variants with a frequency higher than $5 \%$ ), which alone only increase the risk to a small degree (Table 1) $(19,20)$. Rare risk alleles (frequency $<1 \%$ ) and copy-number variants also elevate the risk; they can have relatively strong effects on individuals or within a single family, but account for only a small amount of the variance in the overall population; nicotinergic and glutamatergic systems and genes regulating neural development and synaptogenesis also play a role in the etiology of $\operatorname{ADHD}(21,22)$. Moreover, there are a number of genetic syndromes which are known to be associated with the symptoms of ADHD, including fragile $\mathrm{X}$ syndrome, microdeletion $22 \mathrm{q} 11$ syndrome, tuberous sclerosis, and Williams-Beuren syndrome $(11,23)$.

\section{Environmental risk factors}

Epidemiological studies have shown associations between ADHD and various environmental factors. These primarily include pre- and perinatal risk factors (maternal stress, smoking or alcohol consumption during pregnancy, low birth weight, prematurity), environmental toxins (organophosphates, polychlorinated biphenyls, lead), unfavorable psychosocial conditions (severe early-childhood deprivation, maternal hostility), and dietetic factors $(11,23)$. The causal role of most of these putative environmental risk factors has not yet been proven: The variables are not randomly distributed in the population and the observed associations may be due to confounding factors and selection effects. Moreover, for some variables, causality may lie in the opposite direction, as ADHD itself may lead to increased exposure to certain environmental factors $(11,23$, e27).

Multiple studies have shown that negative mother-child interactions can be a result (but not a cause) of ADHD symptoms in early childhood, but that maternal hostility negatively influences symptoms in the further course of the disorder (e28, e29). The associations of ADHD with prenatal exposure to maternal stress and maternal smoking seem to be partially due to confounding factors, although the association of ADHD with low birth weight, prematurity and lead

\section{Developmentally dependent comorbidities}

Depressive disorders and severe conduct disorders often arise toward the end of the elementary school years and during the transition to adolescence.

\section{Environmental risk factors}

These include the following: maternal stress, cigarette smoking or alcohol consumption during pregnancy, low birth weight, prematurity, environmental toxins, unfavorable psychosocial conditions, and dietetic factors. 


\section{TABLE 1}

Some genetic associations with pooled risk elevation for ADHD (pooled odds ratio) that have been confirmed in meta-analyses*

\begin{tabular}{|l|l|l|c}
\hline \multirow{2}{*}{ Gene } & Gene product & Variant / risk allele & Pooled odds ratio \\
\hline \multirow{2}{*}{ DRD4 } & $\begin{array}{l}\text { Sopamine D4 } \\
\text { receptor }\end{array}$ & $\begin{array}{l}\text { VNTR in exon 3/ } \\
\text { 5-repeat allele }\end{array}$ & 1.33 \\
\cline { 3 - 4 } & $\begin{array}{l}\text { VNTR in exon 3/ } \\
\text { 7-repeat allele }\end{array}$ & 1.68 \\
\cline { 2 - 4 } & $\begin{array}{l}\text { Polymorphism in } \\
\text { promoter/T allele }\end{array}$ & 1.21 \\
\hline DRD5 & $\begin{array}{l}\text { Dopamine D5 } \\
\text { receptor }\end{array}$ & $\begin{array}{l}\text { Dinucleotide repeat/ } \\
\text { 148-bp allele }\end{array}$ & 1.23 \\
\hline DAT1 & $\begin{array}{l}\text { Dopamine } \\
\text { transporter }\end{array}$ & $\begin{array}{l}\text { VNTR in exon 8/ } \\
\text { 3-repeat allele }\end{array}$ & 1.25 \\
\cline { 2 - 4 } & $\begin{array}{l}\text { VNTR in 3-UTR/ } \\
\text { 10-repeat allele }\end{array}$ & 1.17 \\
\cline { 2 - 4 } & $\begin{array}{l}\text { Polymorphism in } \\
\text { 3'-UTR/G allele }\end{array}$ & 1.20 \\
\hline 5HTT & $\begin{array}{l}\text { Serotonin } \\
\text { transporter }\end{array}$ & $\begin{array}{l}\text { 5HTTLPR/ } \\
\text { long allele }\end{array}$ & 1.31 \\
\hline HTR1B & $\begin{array}{l}\text { Serotonin 1B } \\
\text { receptor }\end{array}$ & $\begin{array}{l}\text { Polymorphism in exon } \\
\text { 1/G allele }\end{array}$ & 1.11 \\
\hline
\end{tabular}

ADHD, attention-deficit/hyperactivity disorder; bp, base pair; UTR, untranslated region; VNTR, variable number tandem repeat

*modified from $(17,18,20)$ exposure is probably not explained by confounding variables; they make only a small contribution to the overall variance, however $(23,24$, e29-e31). By contrast, the causal role of severe early childhood deprivation has been demonstrated $(25, \mathrm{e} 32)$.

\section{Neuropsychology}

In group comparisons, studies have shown various neuropsychological impairments in the area of executive functions (inhibitory control, working memory, planning ability) and non-executive functions (regulation of activation and arousal, temporal processing, memory, reaction-time variability). Motivational processes and learning mechanisms are also affected, e.g., an aversion to delayed rewards and reduced behavioral control and error processing mechanisms. However, these impairments and their profile are not specific to ADHD (26, e33, e34); as they show only medium effect sizes, there is considerable overlap with healthy control subjects. Only about half of all persons with ADHD have marked neuropsychological impairment. Currently, it is unclear whether the associated abnormalities are of causal relevance or should rather be seen as epi-phenomena of the etiological mechanisms (26-28, e34, e35).

\section{Structural and functional brain abnormalities}

Global brain volume is reduced by $3-5 \%$, with the gray matter preferentially affected (29, e36, e37). More marked volume loss, correlated with the severity of the symptoms of ADHD, is seen in the prefrontal areas, the basal ganglia, and the cerebellum $(29$, e36). Cortical maturation is delayed, particularly in the prefrontal areas (e38). These abnormalities develop to differing degrees across brain regions and patient populations. The persistence of ADHD symptoms into adulthood is correlated with the persistence of these neuroanatomical abnormalities (e39). Functional imaging reveals hypoactive activation patterns in the prefrontal cortical areas, the anterior cingulate gyrus, and associated parietal, striatal, and cerebellar structures $(29,30$, e38, e40, e41).

The pathophysiological mechanisms of ADHD are not yet adequately understood. On the basis of the available study findings, ADHD is presumed to be multifactorial in most cases. Genetic factors and early environmental risk factors that interact in complex ways to affect the structural and functional development of the brain play a major role and account for a
Structural and functional brain abnormalities The pathophysiological mechanisms of ADHD are not yet adequately understood. On the basis of the available study findings, ADHD is presumed to be multifactorial in most cases.

\section{Diagnostic evaluation}

The diagnostic evaluation integrates information from a detailed developmental history and family history, a psychological diagnostic evaluation, and a physical diagnostic evaluation including a differential diagnostic evaluation. 
high degree of etiological heterogeneity. Each individual factor accounts for only a small part of the variance, i.e., each one is relevant only to a small percentage of affected persons or else has only a weak effect. The risk factors that have been identified are not specific for ADHD; they elevate the risk of other mental illnesses as well, and they also increase the extent of subclinical ADHD symptoms in healthy persons without ADHD. These findings support the hypothesis that ADHD represents one end of a dimension of traits that is continuously distributed in the general population. Its multifactorial etiology corresponds to the heterogeneous overall profile of cerebral structural abnormalities and functional neuropsychological and psychopathological disturbances $(11,23)$.

\section{Diagnostic evaluation}

Like all other neuropsychiatric disorders, ADHD is diagnosed on a clinical basis. No biomarker has yet been found with adequate sensitivity and specificity. Nonetheless, ADHD can be reliably diagnosed if the diagnostic criteria are carefully scrutinized and differential diagnoses are excluded.

The diagnostic evaluation integrates information from a detailed developmental history and family history, a psychological diagnostic evaluation, and a physical diagnostic evaluation including a differential diagnostic evaluation. If the patient is a child or adolescent, the current clinical symptoms and their severity in multiple areas of life are primarily assessed through information from the parents and/or other adults who interact with the child. Information from multiple observers who deal with the patient in different areas of life should always be considered. In adulthood, the diagnostic evaluation is based mainly on talking with the patient, although information from family members or third parties (e.g., school report cards) can be helpful. Useful diagnostic aids include structured or semistructured interviews and checklists to assist in clinical judgments, and disorder-specific questionnaires to determine how the patient is viewed by parents and teachers, as well as by him- or herself. Such questionnaires are now available in German for the diagnosis of ADHD in children, adolescents, and adults according to either the ICD-10 or the DSM-5 (e.g., DISYPS-III, IDA) (e42, e43) (eTable). For diagnosis, the symptoms must have led to a marked impairment of the patient's performance and/or functioning in the social environment. In ADHD/HKD, the degree of severity of the core symptoms is not simply a function of the affected person's age and developmental state. Questionnaires and checklists enable inexpensive, systematic, and standardized data collection from multiple areas of life but may yield misleading findings. If discrepancies in the assessment of the patient remain, it may help to try to resolve these with the aid of more information, which can be obtained over the telephone (e.g., from teachers or carers) or in further face-to-face conversation (e.g., with the patient's grandparents). Persons filling out questionnaires are often reluctant to give answers that cast the child in a negative light, or they may have other personal reasons for giving a modified answer (eTable).

The diagnostic evaluation can also be supplemented with psychological tests, which are necessary when certain specific differential-diagnostic questions have to be answered. About half of all persons with ADHD have normal neurocognitive test findings despite marked core symptoms of the disorder (e33, e34). Reduced intelligence must be ruled out; a valid intelligence assessment (e.g. with the WISC, or with another test such as the CFT-20R for a preliminary assessment) is an obligate component of a comprehensive diagnostic evaluation.

Laboratory tests and ancillary tests can be helpful for the investigation of possibly underlying somatic disease (e.g., thyroid disease, disturbances of sight and hearing, organic sleep disorders, drug-induced disorders) or in differential diagnosis (e.g., to distinguish ADHD from absence epilepsy).

ADHD often needs to be distinguished from a conduct disorder or depression. Very careful distinctions must be drawn between the core symptoms of ADHD (impaired concentration, impulsivity, hyperactivity) and the dissocial and aggressive symptoms that characterize conduct disorder. Further observation over time can clarify whether an observed lack of ability to concentrate combined with heightened irritability is primarily or entirely due to a depressive mood disturbance, rather than being a chronic manifestation of ADHD. Other, less common and very rare differential diagnoses include attachment disorders and schizophrenic and bipolar prodromes.

The clinician must make the diagnosis in the light of all the findings, and not merely on the basis of questionnaires or behavior observation in a test setting in the absence of a thorough developmental history. Differential diagnoses must be considered and ruled out.

\section{Aids for the assessment of ADHD patients}

Remaining discrepancies in the assessment of the patient may be resolved with the aid of further information obtained over the telephone (e.g., from teachers or carers) or in face-to-face conversation (e.g., with the patient's grandparents).

\section{Differential diagnosis}

ADHD often needs to be distinguished from a conduct disorder or depression. The core symptoms of ADHD can be difficult to distinguish from those of a conduct disorder. 
TABLE 2

Non-pharmacological interventions-efficacy with respect to ADHD core manifestations

\begin{tabular}{|c|c|c|c|}
\hline \multirow[t]{2}{*}{ Interventions } & \multicolumn{2}{|c|}{ Effect strength, OR [95\% Cl] } & \multirow[t]{2}{*}{ Remarks } \\
\hline & Unblinded & Blinded & \\
\hline \multicolumn{4}{|l|}{ Dietetic interventions } \\
\hline Elimination diet (32) & $1.48[0.35 ; 2.61]$ & $0.51[-0.02 ; 1.04]$ & Statistically insignificant effect in blinded assessment \\
\hline No artificial coloring (32) & $0.32[0.06 ; 0.58]$ & $0.42[0.13 ; 0.70]$ & $\begin{array}{l}\text { Statistically significant, moderately strong effect in selected cohorts } \\
\text { in blinded assessment }\end{array}$ \\
\hline $\begin{array}{l}\text { Unsaturated fatty acid } \\
\text { supplementation (32) }\end{array}$ & $0.21[0.05 ; 0.36]$ & $0.16[0.01 ; 0.31]$ & $\begin{array}{l}\text { Statistically significant but clinically irrelevant effect in blinded } \\
\text { assessment }\end{array}$ \\
\hline \multicolumn{4}{|l|}{ Psychological interventions } \\
\hline Cognitive training $(32,35)$ & $\begin{array}{l}0.64[0.33 ; 0.95] \\
0.37[0.09 ; 0.66]\end{array}$ & $\begin{array}{l}0.24[-0.24 ; 0.72] \\
0.20[0.01 ; 0.40]\end{array}$ & $\begin{array}{l}\text { Meta-analysis 1: No statistically significant effect in blinded } \\
\text { assessment (32) } \\
\text { Meta-analysis 2: Improvement of working memory in blinded } \\
\text { assessment (verbal: } 0.52 \text { [0.24; } 0.80] \text {; visual: } 0.47[0.23 ; 0.70]) \text { and } \\
\text { small but significant effect on ADHD core manifestations (35) }\end{array}$ \\
\hline Neurofeedback $(32,34)$ & $0.59[0.31 ; 0.87]$ & $0.29[-0.02 ; 0.62]$ & $\begin{array}{l}\text { In blinded assessment, no statistically significant effect when all } \\
\text { studies are included (32); nonetheless, an exploratory secondary } \\
\text { analysis ( } 34 \text { ) reveals a moderately strong, statistically significant } \\
\text { effect with the use of a standardized neurofeedback protocol ( } 0.36 \\
[0.04 ; 0.69])\end{array}$ \\
\hline Behavioral therapy $(32,33)$ & $0.40[0.20 ; 0.60]$ & $0.02[-0.30 ; 0.34]$ & $\begin{array}{l}\text { In blinded assessment, no statistically significant reduction of ADHD } \\
\text { core manifestations ( } 32) \text {, but }(33) \text { there is significant improvement in } \\
\text { positive parenting behavior }(0.63[0.47 ; 0.7]) \text {, reduction in negative } \\
\text { parenting behavior }(0.43[0.24 ; 0.62]) \text {, and reduction of abnormal } \\
\text { conduct }(0.31[0.05 ; 0.57])\end{array}$ \\
\hline
\end{tabular}

ADHD, attention-deficit/hyperactivity disorder; OR, odds ratio; $\mathrm{Cl}$, confidence interval

Nor can the diagnosis of ADHD be made or excluded solely on the basis of psychological testing. The lack of essential information, e.g., prohibition of contact with the school, weakens the validity of the diagnosis.

\section{Treatment}

ADHD is generally treated in the outpatient setting. If outpatient treatment fails due to poor compliance, inadequate family resources, difficult drug adjustments, or impending expulsion from school, it may be necessary to conduct partial or full inpatient treatment. Certain differential diagnostic questions or a complex burden of comorbidities constitute further possible reasons for inpatient treatment.

Treatment guidelines from Germany and abroad now recommend a combination of multiple, individually adapted treatment components (multimodal treatment) (31, e6, e62). The foundation of all therapeutic interven- tions is psychoeducation to impart information about the disorder and potential treatment approaches to the parents, as well as to the child or adolescent patient in an ageappropriate manner. Cognitive behavioral therapy techniques are also used, in both individual and group settings:

- In childhood and adolescence: parent training, interventions in kindergarten and in school, e.g., a therapy program for children with problematic hyperkinetic and oppositional behavior (e63).

- In adulthood: specific psychotherapy manuals.

An unblinded assessment showed low to moderate effects on the core ADHD symptoms, which remained stable even after the end of treatment (32). However, so far, significant effects have not been conclusively demonstrated in blinded assessment (32). By contrast, blinded assessment has revealed positive effects on parental child-rearing behavior, problems of conduct, and the functional level of the affected children (33).

\section{Treatment}

ADHD is usually treated on an outpatient basis.

\section{Therapeutic intervention}

The foundation of all therapeutic interventions is psychoeducation to impart information about the disorder and potential treatment approaches to the parents, as well as to the child or adolescent patient in an age-appropriate manner. 
Approved substances in Germany for the treatment of attention-deficit/hyperactivity disorder

\begin{tabular}{|c|c|c|c|c|c|c|}
\hline & Substance class & Typical dose range & $\begin{array}{l}\text { Effect } \\
\text { strength }\end{array}$ & $\begin{array}{l}\text { Number } \\
\text { needed } \\
\text { to treat }\end{array}$ & Adverse effects & Remarks \\
\hline $\begin{array}{l}\text { Methylphenidate } \\
\text { (MPH) }\end{array}$ & Psychostimulant & $0.3-1.0 \mathrm{mg} / \mathrm{kg}$ BW & $0.8-1.0$ & $\begin{array}{l}\text { ca. } 2.5 \\
\text { (e81) }\end{array}$ & \multirow{3}{*}{$\begin{array}{l}\text { On average, mild increase in } \\
\text { blood pressure and heart rate; } \\
\text { appetite suppression, weight } \\
\text { loss, abdominal pain, head- } \\
\text { ache, difficulty falling asleep, } \\
\text { insomnia, emotional irritability, } \\
\text { intensification of tic manifesta- } \\
\text { tions if already present }\end{array}$} & $\begin{array}{l}\text { Drug of first choice; } \\
\text { sustained-release prepara- } \\
\text { tions are available (e81, e82) }\end{array}$ \\
\hline Dexamfetamine & Psychostimulant & $0.1-0.5 \mathrm{mg} / \mathrm{kg} \mathrm{BW}$ & $0.8-1.0$ & $\begin{array}{l}\text { ca. } 2 \\
\text { (e82) }\end{array}$ & & $\begin{array}{l}\text { Efficacy and tolerability } \\
\text { comparable to that of MPH; } \\
\text { approved if MPH is not suffi- } \\
\text { ciently effective (e81, e82) }\end{array}$ \\
\hline Lisdexamfetamine & Psychostimulant & $30-70 \mathrm{mg}$ & $\varnothing 1.0$ & & & $\begin{array}{l}\text { Prodrug with prolonged effect; } \\
\text { approved in Germany if the } \\
\text { response to MPH is inade- } \\
\text { quate (e83) }\end{array}$ \\
\hline Atomoxetine & $\begin{array}{l}\text { Selective norepi- } \\
\text { nephrine reuptake } \\
\text { inhibitor (SNRI) }\end{array}$ & $1.2 \mathrm{mg} / \mathrm{kg} \mathrm{BW}$ & $0.5-0.7$ & $\begin{array}{l}\text { ca. } 4 \\
\text { (e84) }\end{array}$ & $\begin{array}{l}\text { On average, mild increase in } \\
\text { blood pressure and heart rate; } \\
\text { mild shortening of QTC, dry } \\
\text { mouth, appetite suppression, } \\
\text { weight loss, gastrointestinal } \\
\text { symptoms, dizziness, head- } \\
\text { ache, drowsiness, fatigue, } \\
\text { sedation }\end{array}$ & $\begin{array}{l}\text { Drug of first choice in the } \\
\text { presence of a comorbid tic, } \\
\text { anxiety, or substance dis- } \\
\text { order; otherwise, drug of } \\
\text { second choice (e84) }\end{array}$ \\
\hline Guanfacine & $\begin{array}{l}\text { Central } \\
a_{2} \text {-agonist }\end{array}$ & $1-5 \mathrm{mg}$ & 0.6 & $\begin{array}{l}\text { ca. } 4 \\
\text { (e85) }\end{array}$ & $\begin{array}{l}\text { Fatigue, sedation, somno- } \\
\text { lence, mild lowering of blood } \\
\text { pressure and heart rate, mild } \\
\text { QTc prolongation }\end{array}$ & $\begin{array}{l}\text { Sustained-release preparation } \\
\text { available as a drug of second } \\
\text { choice if MPH is ineffective or } \\
\text { poorly tolerated; metabolized } \\
\text { by CYP3A4 (e85, e86) }\end{array}$ \\
\hline
\end{tabular}

BW, body weight

Meta-analyses have shown that food supplementation with unsaturated fatty acids has a weakly statistically significant but clinically irrelevant effect on the core symptoms of ADHD (32). Nor are any other dietetic measures generally of therapeutic use. The utility of neurofeedback as part of a multimodal overall treatment plan remains unclear (34). So far, an insufficient number of studies with high-quality training protocols have been performed. Such studies would probably yield better results than other approaches (Table 2).

Alongside these treatments, pharmacotherapy (Table 3 ) is a further essential component of ADHD treatment. The efficacy and tolerability of treatment with stimulants have been demonstrated repeatedly in many metaanalyses, e.g., that of the National Institute of Excellence (e6). A recent Cochrane Review (36) cast doubt on the quality of the evidence supporting the efficacy of methylphenidate. This review, however, was widely criticized by experts around the world and aroused vigorous debate due to its unusually strict categorizations of bias, questionable inclusion criteria, methodological errors, and an inadmissible clinical interpretation of the data $(36,37$, e64-e69).

Randomized trials on the long-term efficacy of treating ADHD with stimulants cannot be performed for ethical reasons. The last three decades have seen a marked rise in the number of studies on the long-term results of treatment (e70, e71). Longitudinal studies of brain development (e36, e72, e73) have revealed a structural normalization of brain development under treatment with stimulants. The findings of Scandinavian registry studies that have been adjusted for potential confounding factors suggest that drug treatment for ADHD reduces the risk of delinquent behavior (38), substance abuse (e74), suicidal behavior (e75),

\section{Positive effects}

Cognitive behavioral therapy techniques have positive effects on parental child-rearing behavior, problems of conduct, and the functional level of the affected children.

\section{Pharmacotherapy}

Pharmacotherapy is an essential component of the treatment of ADHD. 
and accidents (e76) to a statistically significant and clinically relevant extent. Further studies have also shown a reduction of functional impairment and an improvement in health-related quality of life (e77). In general, (drug) treatment leads to a more favorable temporal course of the core symptoms, associated psychiatric disorders, and relevant functional impairments, even though a fully normal state still cannot be achieved in most cases (e71, e78, e79).

The decision for drug treatment should be made only after careful consideration in all cases, as should the further decisions about when to treat, for what duration, and at what dosage. Behavioral therapy is always preferable to drug therapy for preschool children and for school-age children with only mild symptoms. Primary treatment with drugs is indicated from school age onward in the case of pronounced and situationally independent ADHD symptoms that are causing marked functional impairment (e6). Moreover, there is evidence to support primary drug treatment for some children with moderate ADHD symptoms. For adults with ADHD, drugs are the first line of treatment (e80). Patients must be followed up regularly over the long term to check for possible side effects of drug treatment; in particular, their blood pressure, heart rate, height, and weight should be regularly monitored (39). The effect of treatment should also be monitored with regular brief periods of discontinuation of the drug, generally once per year (39).

For the treatment of associated mental disorders, further psychotherapeutic interventions on the basis of behavioral therapy, family systems therapy, or depth psychology may be helpful. Drugs may also be useful to treat certain comorbid psychiatric problems such as depression, tic disorders, and obsessive-compulsive disorder.

\section{Overview}

ADHD is a developmental disorder that has not become any more prevalent in the general population in recent decades but that has nonetheless become increasingly well recognized. As it leads to functional impairment in multiple areas of life, is often associated with the development of comorbid mental disorders, and can have lifelong adverse consequences for the patient, ADHD requires early, need- and age-adapted treatment consisting of psychoeducation, behavioral therapy, and treatment with psychoactive drugs. There are effective methods of treatment for both the core and accompany-

\section{Primary drug treatment}

Primary treatment with drugs is indicated from school age onward if pronounced and situationally independent ADHD symptoms are present that are causing marked functional impairment. ing symptoms of ADHD. As part of the nationwide research network on mental illness supported by the German Federal Ministry of Education and Research (Bundesministerium für Bildung und Forschung, BMBF), the ESCAlife Association (a German acronym for "evidence-based, multilevel care of ADHD over a lifetime"; www.esca-life.org) is now studying the efficacy and cost-effectiveness of individualized and stepwise multimodal treatment programs for ADHD and is trying to identify predictors of the individual response to treatment.

\section{Conflict of interest statement}

Prof. Banaschewski has served as a paid consultant for Lilly, Medice, Novartis, Shire, Otsuka, and Actelion. He has received payment for publications from Hogrefe, Thieme, CIP Medien, and Oxford University Press. He has served as a paid consulting medical expert for Hexal. He has received reimbursement of meeting participation fees and of travel and accommodation expenses from Shire, Medice, and Novartis and has also been paid by these firms for organizing continuing medical education events. He has received financial and material support from Viforpharma for a research project that he initiated.

Prof. Becker has received consultant's fees and reimbursement of meeting participation fees and of travel and accommodation expenses from Lilly, as well as scientific lecture honoraria from Shire.

Prof. Döpfner has served as a paid consultant for Medice, Shire, Lilly, and Vifor. He has received payment for publications from Hogrefe, Huber, Guilford, and Kohlhammer. He has received reimbursement of meeting participation fees and of travel and accommodation expenses as well as scientific lecture honoraria from Shire, Medice, Lilly, and Vifor. He has received financial support for a research project that he initiated from Vifor, Medice, Lilly, Novartis, and Shire, as well as material support from Vifor, Medice, Lilly, and Shire.

Prof. Holtmann has served as a paid consultant for Lilly Deutschland, Shire, and Medice. He has received reimbursement of travel and accommodation expenses from Medice and Shire and lecture honoraria from Medice, Shire, Lilly, and neuroConn.

Prof. Rösler receives royalties from Hogrefe Verlag. He serves as a paid consultant for Medice, Shire, and Lilly. He has received lecture honoraria from Medice and Shire. He has received financial support for a research project that he initiated from Vifor and material support for the performance of clinical trials from Medice.

Prof. Romanos has served as a paid consultant for AOK Baden-Württemberg.

Manuscript submitted on 1 August 2016, revised version accepted on 11 January 2017.

Translated from the original German by Ethan Taub, M.D.

\section{REFERENCES}

1. American Psychiatric Association: Diagnostic and statistica manual of mental disorders: DSM-5. Washington, D.C.: American Psychiatric Association 2013.

2. WHO: The ICD-10 classification of mental and behavioural disorders: clinical descriptions and diagnostic guidelines. Geneva: WHO 1992.

3. Polanczyk G, de Lima MS, Horta BL, Biederman J, Rohde LA The worldwide prevalence of ADHD: a systematic review and metaregression analysis. Am J Psychiatry 2007; 164: 942-8.

4. Simon V, Czobor P, Balint S, Meszaros A, Bitter I: Prevalence and correlates of adult attention-deficit hyperactivity disorder: metaanalysis. Br J Psychiatry 2009; 194: 204-11.

5. Faraone SV, Biederman J, Mick E: The age-dependent decline of attention deficit hyperactivity disorder: a meta-analysis of follow-up studies. Psychol Med 2006; 36: 159-65.

6. Polanczyk GV, Willcutt EG, Salum GA, Kieling C, Rohde LA: ADHD prevalence estimates across three decades: an updated systematic review and meta-regression analysis. Int J Epidemiol 2014; 43: 434-42. 
7. Shaw P, Stringaris A, Nigg J, Leibenluft E: Emotion dysregulation in attention deficit hyperactivity disorder. Am J Psychiatry 2014; 171: 276-93.

8. Sobanski E, Banaschewski T, Asherson P, et al.: Emotional lability in children and adolescents with attention deficit/hyperactivity disorder (ADHD): clinical correlates and familial prevalence. J Child Psychol Psychiatry 2010; 51: 915-23.

9. Dalsgaard S, Ostergaard SD, Leckman JF, Mortensen PB, Pedersen MG: Mortality in children, adolescents, and adults with attention deficit hyperactivity disorder: a nationwide cohort study. Lancet 2015; 385: 2190-6.

10. Danckaerts M, Sonuga-Barke EJ, Banaschewski T, et al.: The quality of life of children with attention deficit/hyperactivity disorder: a systematic review. Eur Child Adolesc Psychiatry 2010; 19: 83-105.

11. Faraone SV, Asherson P, Banaschewski T, et al.: Attention-deficit/hyperactivity disorder. Nat Rev Dis Primers 2015; 1: 15020.

12. Erskine HE, Norman RE, Ferrari AJ, et al.: Long-term outcomes of attention-deficit/hyperactivity disorder and conduct disorder: a systematic review and meta-analysis. J Am Acad Child Adolesc Psychiatry 2016; 55: 841-50.

13. Barkley RA, Fischer M, Smallish L, Fletcher K: Young adult outcome of hyperactive children: adaptive functioning in major life activities. J Am Acad Child Adolesc Psychiatry 2006; 45: 192-202.

14. Moffitt TE, Houts R, Asherson P, et al.: Is adult ADHD a childhood-onset neurodevelopmental disorder? Evidence from a four-decade longitudinal cohort study. Am J Psychiatry 2015; 172: $967-77$.

15. Jensen CM, Steinhausen HC: Comorbid mental disorders in children and adolescents with attention-deficit/hyperactivity disorder in a large nationwide study. Atten Defic Hyperact Disord 2015; 7: 27-38.

16. Taurines R, Schmitt J, Renner T, Conner AC, Warnke A, Romanos M: Developmental comorbidity in attention-deficit/hyperactivity disorder. Atten Defic Hyperact Disord 2010; 2: 267-89.

17. Faraone SV, Perlis RH, Doyle AE, et al.: Molecular genetics of attention-deficit/hyperactivity disorder. Biol Psychiatry 2005; 57: 1313-23

18. Gizer IR, Ficks C, Waldman ID: Candidate gene studies of ADHD: a meta-analytic review. Hum Genet 2009; 126: 51-90.

19. Neale BM, Medland SE, Ripke S, et al.: Meta-analysis of genome-wide association studies of attention-deficit/hyperactivity disorder. J Am Acad Child Adolesc Psychiatry 2010; 49: 884-97.

20. Thapar A, Cooper M, Eyre 0, Langley K: What have we learnt about the causes of ADHD? J Child Psychol Psychiatry 2013; 54: 3-16.

21. Elia J, Gai X, Xie HM, et al.: Rare structural variants found in attention-deficit hyperactivity disorder are preferentially associated with neurodevelopmental genes. Mol Psychiatry 2010; 15: 637-46.

22. Elia J, Glessner JT, Wang K, et al.: Genome-wide copy number variation study associates metabotropic glutamate receptor gene networks with attention deficit hyperactivity disorder. Nat Genet 2012; 44: 78-84.

23. Thapar A, Cooper M: Attention deficit hyperactivity disorder Lancet 2016; 387: 1240-50.

24. D‘Onofrio BM, Rickert ME, Langstrom N, et al.: Familial confounding of the association between maternal smoking during pregnancy and offspring substance use and problems. Arch Gen Psychiatry 2012; 69: 1140-50.

25. Kennedy M, Kreppner J, Knights N, et al.: Early severe institutional deprivation is associated with a persistent variant of adult attention-deficit/hyperactivity disorder: clinical presentation, developmental continuities and life circumstances in the English and Romanian Adoptees study. J Child Psychol Psychiatry 2016; 57 : 1113-25.
26. Coghill DR, Seth S, Matthews K: A comprehensive assessment of memory, delay aversion, timing, inhibition, decision making and variability in attention deficit hyperactivity disorder: advancing beyond the three-pathway models. Psychol Med 2014; 44: 1989-2001.

27. Coghill DR, Hayward D, Rhodes SM, Grimmer C, Matthews K: A longitudinal examination of neuropsychological and clinical functioning in boys with attention deficit hyperactivity disorder (ADHD): improvements in executive functioning do not explain clinical improvement. Psychol Med 2014; 44: 1087-99.

28. Plichta MM, Scheres A: Ventral-striatal responsiveness during reward anticipation in ADHD and its relation to trait impulsivity in the healthy population: a meta-analytic review of the fMR literature. Neurosci Biobehav Rev 2014; 38: 125-34.

29. Castellanos FX, Lee PP, Sharp W, et al.: Developmental trajectories of brain volume abnormalities in children and adolescents with attention-deficit/hyperactivity disorder. JAMA 2002; 288: 1740-8.

30. Shaw P, Malek M, Watson B, Greenstein D, de Rossi P, Sharp W: Trajectories of cerebral cortical development in childhood and adolescence and adult attention-deficit/hyperactivity disorder. Biol Psychiatry 2013; 74: 599-606.

31. Taylor E, Döpfner M, Sergeant J, et al.: European clinical guidelines for hyperkinetic disorder-first upgrade. Eur Child Adolesc Psychiatry 2004; 13 Suppl 1: 17-30.

32. Sonuga-Barke EJ, Brandeis D, Cortese S, et al.: Nonpharmacological interventions for ADHD: systematic review and metaanalyses of randomized controlled trials of dietary and psychological treatments. Am J Psychiatry 2013; 170: 275-89.

33. Daley D, van der Oord S, Ferrin M, et al.: Behavioral interventions in attention-deficit/hyperactivity disorder: a meta-analysis of randomized controlled trials across multiple outcome domains. J Am Acad Child Adolesc Psychiatry 2014; 53: 835-47.

34. Cortese S, Ferrin M, Brandeis D, et al.: Neurofeedback for attention-deficit/hyperactivity disorder: meta-analysis of clinical and neuropsychological outcomes from randomized controlled trials. J Am Acad Child Adolesc Psychiatry 2016; 55: 444-55.

\section{Further information on $\mathrm{CME}$}

This article has been certified by the North Rhine Academy for Postgraduate and Continuing Medical Education. Deutsches Ärzteblatt provides certified continuing medical education (CME) in accordance with the requirements of the Medical Associations of the German federal states (Länder). CME points of the Medical Associations can beacquired only through the Internet, not by mail or fax, by the use of the German version of the CME questionnaire. See the following website: cme.aerzteblatt.de

Participants in the CME program can manage their CME points with their 15-digit "uniform CME number" (einheitliche Fortbildungsnummer, EFN). The EFN must be entered in the appropriate field in the cme.aerzteblatt.de website under "meine Daten" ("my data"), or upon registration. The EFN appears on each participant's CME certificate.

This CME unit can be accessed until 28 May 2017, and earlier CME units until the dates indicated:

- "Pulmonary Hypertension" (Issue 5/2017) until 30 April 2017,

- "Hepatitis C" (Issue 1-2/2017) until 2 April 2017. 
35. Cortese S, Ferrin M, Brandeis D, et al.: Cognitive training for attention-deficit/hyperactivity disorder: meta-analysis of clinical and neuropsychological outcomes from randomized controlled trials. J Am Acad Child Adolesc Psychiatry 2015; 54: 164-74.

36. Storebø OJ, Ramstad E, Krogh HB, et al.: Methylphenidate for children and adolescents with attention deficit hyperactivity disorder (ADHD). Cochrane Database Syst Rev 2015: CD009885.

37. Banaschewski T, Gerlach M, Becker K, Holtmann M, Döpfner M, Romanos M: Trust, but verify. The errors and misinterpretations in the cochrane analysis by 0 . J. Storebø and colleagues on the efficacy and safety of methylphenidate for the treatment of children and adolescents with ADHD. Z Kinder Jugendpsychiatr Psychother 2016; 44: 307-14.

38. Lichtenstein P, Larsson $\mathrm{H}$ : Medication for attention deficit-hyperactivity disorder and criminality. N Engl J Med 2013; 368: 776
39. Cortese S, Holtmann M, Banaschewski T, et al.: Practitioner review: current best practice in the management of adverse events during treatment with ADHD medications in children and adolescents. J Child Psychol Psychiatry 2013; 54: 227-46.

\section{Corresponding author}

Prof. Dr. med. Dr. rer. nat. Tobias Banaschewski

Zentralinstitut für Seelische Gesundheit J5

68159 Mannheim, Germany

tobias.banaschewski@zi-mannheim.de

\section{Supplementary materia}

For eReferences please refer to:

www.aerzteblatt-international.de/ref0917

eTable:

www.aerzteblatt-international.de/17m0149

\section{CLINICAL SNAPSHOT}

\section{Is Idiopathic Always Idiopathic? What the Teeth Can Tell Us}

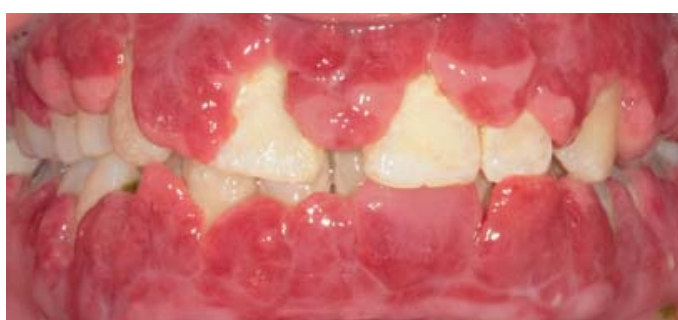

The initial findings: gingival hyperplasia
A 25-year-old woman presented to the periodontology clinic of the dental hospital because of generalized hyperplastic swelling of the gingiva. Her fasting blood sugar was normal (01/2013: $97 \mathrm{mg} / \mathrm{dL})$, but her inflammatory parameters were elevated (01/ 2013: ESR $90 \mathrm{~mm} / \mathrm{hr}$, CRP $1.9 \mathrm{mg} / \mathrm{dL}$, WBC 11.1/nL). Her body-mass index (BMI) was over 30 . As there was no other evidence of systemic illness and her medication use was unknown, the initially presumed diagnosis was of idiopathic gingival hyperplasia associated with chronic periodontitis. Systematic non-surgical periodontal treatment along with adjuvant antibiotics led to moderate improvement, but the hyperplasia did not resolve. Repeated laboratory testing one year later revealed an elevated fasting blood sugar (03/2014: $204 \mathrm{mg} / \mathrm{dL})$ and an $\mathrm{HbA}$, value of $9.5 \%$. Antidiabetic treatment and continued local mechanical treatment led to the near-total resolution of gingival hyperplasia.

We conclude from this case that patients who present with gingival hyperplasia should undergo intensified diagnostic testing for diabetes mellitus even if their initial fasting blood sugar is normal.

Prof. Dr. med. dent. Anton Friedmann, Dr. med. dent. Matthias Becker, Department Zahn-, Mund-, Kieferheilkunde, Universität Witten/Herdecke, Lehrstuhl für Parodontologie

Prof. Dr. med. Hans Jürgen Heppner, Lehrstuhl für Geriatrie Universität Witten/Herdecke, HELIOS Klinikum Schwelm, Klinik für Geriatrie, Hans.Heppner@uni-wh.de

\section{Conflict of interest statement}

The authors state that they have no conflict of interest.

Translated from the original German by Ethan Taub, MD.

Cite this as:

Friedmann A, Becker M, Heppner J: Is idiopathic always idiopathic? What the teeth can tell us. Dtsch Arztebl Int 2017; 114: 158. D0I: 10.3238/arztebl.2017.0158 


\section{Question 1}

What is the worldwide epidemiological prevalence of attention-deficit/hyperactivity disorder (ADHD) in childhood and adolescence, according to the DSM-IV criteria?
a) Approximately $1.8 \%$
b) Approximately $2.7 \%$
c) Approximately 3.9\%
d) Approximately $5.3 \%$
e) Approximately $7.1 \%$

\section{Question 2}

The diagnosis of hyperkinetic disorder (HKD) according to the ICD-10 requires the fulfillment of certain diagnostic criteria. Which of the following is an obligate criterion?
a) Persistent, situationally independent symptoms for at least 12 months
b) At least average intelligence
c) Exclusion of dyslexia
d) Demonstration of at least one underlying neuropsychological abnormality (e.g. aversion to delayed reward, high reaction time variability)
e) The extent of the core symptoms is beyond that expected for the patient's age and state of development

\section{Question 3}

Which of the following is an essential part of a comprehensive diagnostic work-up for ADHD?
a) Complete blood count
b) Intelligence test
c) Positron-emission tomography scan of the brain
d) Rorschach test
e) Mobility test

\section{Question 4}

Which of the following is a risk factor for a severe course of ADHD and elevates the probability that the disorder will persist?
a) An unfavorable psychosocial environment
b) A negative family history of ADHD
c) Core symptoms of only mild intensity
d) Female sex
e) High intelligence

\section{Question 5}

Persons with ADHD have a higher mortality than the general population for multiple reasons, including accident-proneness and a higher suicide rate. By what amount is the mortality of persons with ADHD elevated?
a) $10 \%$
b) $30 \%$
c) $50 \%$
d) $70 \%$
e) $90 \%$

Question 6

By what factor is the risk of ADHD elevated among first-degree relatives of persons with ADHD?
a) 5 - to 10 -fold
b) 10 - to 15 -fold
c) 15 - to 20 -fold
d) 20 - to 25 -fold
e) 25- to 30 -fold

Question 7

What mental or psychosomatic comorbidity of ADHD tends to arise early in child development?
a) Oppositional defiant disorder
b) Functional abdominal complaints
c) Depression
d) Schizophrenia
e) Anorexia nervosa

Question 8

What environmental factor have epidemiological studies shown to be associated with ADHD in childhood?

a) Cannabis consumption by the patient

b) High educational level of the parents

c) Being an only child

d) Extensive television-watching

e) Intrauterine nicotine exposure

\section{Question 9}

Which of the following is the foundation of appropriate therapeutic intervention for ADHD?
a) Psychoeducation
b) Confrontation therapy
c) Aggression training
d) Autogenic training
e) Jacobsen relaxation exercises

Question 10

Which of the following drugs (among others) can be used to treat ADHD if the patient does not respond to methylphenidate?
a) Promethazine
b) Lisdexamfetamine
c) Clomethiazole
d) Olanzapine
e) Haloperidol 
Supplementary material to:

Attention-Deficit/Hyperactivity Disorder

A Current Overview

By Tobias Banaschewski, Katja Becker, Manfred Döpfner, Martin Holtmann, Michael Rösler, and Marcel Romanos

Dtsch Arztebl Int 2017; 114: 149-59. D0I: 10.3238/arztebl.2017.0149

\section{eREFERENCES}

e1. Larsson H, Anckarsater H, Rastam M, Chang Z, Lichtenstein P: Childhood attention-deficit hyperactivity disorder as an extreme of a continuous trait: a quantitative genetic study of 8,500 twin pairs. J Child Psychol Psychiatry 2012; 53: 73-80.

e2. Valo S, Tannock R: Diagnostic instability of DSM-IV ADHD subtypes: effects of informant source, instrumentation, and methods for combining symptom reports. J Clin Child Adolesc Psychol 2010; 39: 749-60.

e3. Banaschewski T, Döpfner M: [DMS-5—attention-deficit/hyperactivity disorder]. Z Kinder Jugendpsychiatr Psychother 2014; 42: 271-5; quiz 6-7.

e4. Kieling C, Kieling RR, Rohde LA, et al.: The age at onset of attention deficit hyperactivity disorder. Am J Psychiatry 2010; 167: 14-6.

e5. Wittchen HU, Jacobi F, Rehm J, et al.: The size and burden of mental disorders and other disorders of the brain in Europe 2010. Eur Neuropsychopharmacol 2011; 21: 655-79.

e6. National Institute for Health and Clinical Excellence: Diagnosis and management of ADHD in children, young people and adults. Great Britain: The British Psychological Society \& The Royal College of Psychiatrists 2009.

e7. Döpfner M, Breuer D, Wille N, Erhart M, Ravens-Sieberer U, Bella study group: How often do children meet ICD-10/DSM-IV criteria of attention deficit-/hyperactivity disorder and hyperkinetic disorder? Parent-based prevalence rates in a national sample-results of the BELLA study. Eur Child Adolesc Psychiatry 2008; 17 (Suppl 1): 59-70.

e8. Polanczyk G, Rohde LA: Epidemiology of attention-deficit/hyperactivity disorder across the lifespan. Current Opinion in Psychiatry 2007; 20: 386-92.

e9. Larsson H, Sariaslan A, Langstrom N, D‘Onofrio B, Lichtenstein P: Family income in early childhood and subsequent attention deficit/hyperactivity disorder: a quasi-experimental study. J Child Psychol Psychiatry 2014; 55: 428-35.

e10. Erskine HE, Ferrari AJ, Polanczyk GV, et al.: The global burden of conduct disorder and attention-deficit/hyperactivity disorder in 2010. J Child Psychol Psychiatry 2014; 55: 328-36

e11. Retz W, Stieglitz RD, Corbisiero S, Retz-Junginger P, Rosler M: Emotional dysregulation in adult ADHD: what is the empirical evidence? Expert Rev Neurother 2012; 12: 1241-51.

e12. Lara C, Fayyad J, de Graaf R, et al.: Childhood predictors of adult attention-deficit/hyperactivity disorder: results from the World Health Organization World Mental Health Survey Initiative. Biol Psychiatry 2009; 65: 46-54.

e13. Biederman J, Petty CR, Clarke A, Lomedico A, Faraone SV: Predictors of persistent ADHD: an 11-year follow-up study. J Psychiatr Res 2011; 45: 150-5.

e14. Riglin L, Collishaw S, Thapar AK, et al.: Association of genetic risk variants with attention-deficit/hyperactivity disorder trajectories in the general population. JAMA Psychiatry 2016; 73: 1285-92

e15. Harold GT, Leve LD, Barrett D, et al.: Biological and rearing mother influences on child ADHD symptoms: revisiting the developmental interface between nature and nurture. J Child Psychol Psychiatry 2013; 54: 1038-46.

e16. Roy A, Hechtman L, Arnold LE, et al.: Childhood factors affecting persistence and desistence of attention-deficit/hyperactivity disorder symptoms in adulthood: results from the MTA. J Am Acad Child Adolesc Psychiatry 2016; 55: 937-44 e4. e17. Bussing R, Mason DM, Bell L, Porter P, Garvan C: Adolescent outcomes of childhood attention-deficit/hyperactivity disorder in a diverse community sample. J Am Acad Child Adolesc Psychiatry 2010; 49: 595-605

e18. Chronis-Tuscano A, Degnan KA, Pine DS, et al.: Stable early maternal report of behavioral inhibition predicts lifetime socia anxiety disorder in adolescence. J Am Acad Child Adolesc Psychiatry 2009; 48: 928-35.

e19. Stickley A, Koyanagi A, Ruchkin V, Kamio Y: Attention-deficit/hyperactivity disorder symptoms and suicide ideation and attempts: findings from the Adult Psychiatric Morbidity Survey 2007. J Affect Disord 2016; 189: 321-8.

e20. Caye A, Rocha TB, Anselmi L, et al.: Attention-deficit/hyperactivity disorder trajectories from childhood to young adulthood: evidence from a birth cohort supporting a late-onset syndrome. JAMA Psychiatry 2016; 73: 705-12.

e21. Faraone SV, Biederman J: Can attention-deficit/hyperactivity disorder onset occur in adulthood? JAMA Psychiatry 2016; 73 655-6.

e22. Biederman J, Newcorn J, Sprich S: Comorbidity of attention deficit hyperactivity disorder with conduct, depressive, anxiety, and other disorders. Am J Psychiatry 1991; 148: 564-77.

e23. Jensen PS, Martin D, Cantwell DP: Comorbidity in ADHD: Implications for research, practice, and DSM-V. J Am Acad Child Adolesc Psychiatry 1997; 36: 1065-79.

e24. Jacob CP, Romanos J, Dempfle A, et al.: Co-morbidity of adult attention-deficit/hyperactivity disorder with focus on personality traits and related disorders in a tertiary referral center. Eur Arch Psychiatry Clin Neurosci 2007; 257: 309-17.

e25. Biederman J, Faraone SV, Keenan K, Tsuang MT: Evidence of familial association between attention deficit disorder and major affective disorders. Arch Gen Psychiatry 1991; 48: 633-42.

e26. Biederman J, Faraone SV, Mick E, et al.: High risk for attention deficit hyperactivity disorder among children of parents with childhood onset of the disorder: a pilot study. Arch Gen Psychiatry 1995; 152: 431-5.

e27. Lahey BB, D'Onofrio BM, Waldman ID: Using epidemiologic methods to test hypotheses regarding causal influences on child and adolescent mental disorders. J Child Psychol Psychiatry 2009; 50: 53-62

e28. Grizenko N, Shayan YR, Polotskaia A, Ter-Stepanian M, Joober R: Relation of maternal stress during pregnancy to symptom severity and response to treatment in children with ADHD. J Psychiatry Neurosci 2008; 33: 10-6.

e29. Nigg JT, Nikolas M, Mark Knottnerus G, Cavanagh K, Friderici K: Confirmation and extension of association of blood lead with attention-deficit/hyperactivity disorder (ADHD) and ADHD symptom domains at population-typical exposure levels. J Child Psychol Psychiatry 2010; 51: 58-65.

e30. Groen-Blokhuis MM, Middeldorp CM, van Beijsterveldt CE, Boomsma Dl: Evidence for a causal association of low birth weight and attention problems. J Am Acad Child Adolesc Psychiatry 2011; 50: 1247-54 e2.

e31. Thapar A, Rice F, Hay D, et al.: Prenatal smoking might not cause attention-deficit/hyperactivity disorder: evidence from a novel design. Biol Psychiatry 2009; 66: 722-7.

e32. Kreppner JM, O'Connor TG, Rutter M, English and Romanian Adoptees Study Team: Can inattention/overactivity be an institutional deprivation syndrome? J Abnorm Child Psychol 2001; 29: 513-28. 
e33. Willcutt E, Sonuga-Barke EJ, Nigg J, Sergeant JA: Recent developments in neuropsychological models of childhood psychiatric disorders. In: Banaschewski T, Rohde LA, (eds.): Biological child psychiatry recent trends and developments. Basel: Karger 2008: 195-226.

e34. Willcutt EG, Doyle AE, Nigg JT, Faraone SV, Pennington BF: Validity of the executive function theory of attention-deficit/hyperactivity disorder: a meta-analytic review. Biol Psychiatry 2005; 57: 1336-46.

e35. van Lieshout M, Luman M, Buitelaar J, Rommelse NN, Oosterlaan $\mathrm{J}$ : Does neurocognitive functioning predict future or persistence of ADHD? A systematic review. Clin Psychol Rev 2013; 33: 539-60.

e36. Frodl T, Skokauskas N: Meta-analysis of structural MRI studies in children and adults with attention deficit hyperactivity disorder indicates treatment effects. Acta Psychiatr Scand 2012; 125: 114-26.

e37. Greven CU, Bralten J, Mennes M, et al.: Developmentally stable whole-brain volume reductions and developmentally sensitive caudate and putamen volume alterations in those with attentiondeficit/hyperactivity disorder and their unaffected siblings. JAMA Psychiatry 2015; 72: 490-9.

e38. Shaw P, Eckstrand K, Sharp W, et al.: Attention-deficit/hyperactivity disorder is characterized by a delay in cortical maturation. Proc Natl Acad Sci U S A 2007; 104: 19649-54.

e39. Shaw P, Malek M, Watson B, Sharp W, Evans A, Greenstein D: Development of cortical surface area and gyrification in attentiondeficit/hyperactivity disorder. Biol Psychiatry 2012; 72: 191-7.

e40. Cortese S, Kelly C, Chabernaud C, et al.: Toward systems neuroscience of ADHD: a meta-analysis of $55 \mathrm{fMRl}$ studies. Am J Psychiatry 2012; 169: 1038-55.

e41. Hart H, Radua J, Nakao T, Mataix-Cols D, Rubia K: Meta-analysis of functional magnetic resonance imaging studies of inhibition and attention in attention-deficit/hyperactivity disorder: exploring task-specific, stimulant medication, and age effects. JAMA Psychiatry 2013; 70: 185-98.

e42. Döpfner M, Görtz-Dorten A: Diagnostik-System für psychische Störungen nach ICD-10 und DSM-5 für Kinder- und Jugendliche (DISYPS-III). Bern: Hogrefe 2017.

e43. Retz W, Retz-Junginger W, Rösler M: IDA. Integrierte Diagnose der ADHS im Erwachsenenalter. Homburg/Saar: Universitätsklinik des Saarlandes, Neurozentrum 2012.

e44. Delmo C, Weiffenbach O, Gabriel M, Stadler C and Poustka F: Diagnostisches Interview Kiddie-SADS-Present and Lifetime Version (K-SADS-PL). $5^{\text {th }}$ edition of the German research version with the addition of ICD-10-diagnosis. Juli 2000/Juli2001. Available at: www.adhs-legasthenie.de/PDF/K-SADS_Fragebogen.pdf (last accessed on 31 January 2017).

e45. Schneider S, Unnewehr S, Margraf J: Diagnostisches Interview bei psychischen Störungen im Kindes- und Jugendalter (KinderDIPS). Heidelberg: Springer 2009.

e46. Döpfner M, Görtz-Dorten A: Diagnostik-System für psychische Störungen nach ICD-10 und DSM-5 für Kinder- und Jugendliche (DISYPS-III). Bern: Hogrefe 2016.

e47. Rösler M, Retz-Junginger P, Retz W, Stieglitz RD: HASE. Homburger ADHS-Skalen für Erwachsene. Untersuchungsverfahren zur syndromalen und kategorialen Diagnostik der Aufmerksamkeitsdefizit-/Hyperaktivitätsstörung (ADHS) im Erwachsenenalter. Göttingen: Hogrefe 2008.

e48. Lidzba K, Christiansen H, Drechsler RH: Conners Skalen zu Aufmerksamkeit und Verhalten - 3; Deutschsprachige Adaptation der Conners $3^{\text {rd }}$ ed (Conners 3) von C. Keith Conners. Göttingen: Huber 2013.

e49. Stiensmeier-Pelster J, Braune-Krickau M, Schürmann M, Duda K Depressionsinventar für Kinder und Jugendliche. $3^{\text {rd }} \mathrm{ed}$. Göttingen: Hogrefe 2014.

e50. Hautzinger M, Keller F, Kühner C: Beck Depressions-Inventar (BDI-II). Revision. Deutsche Bearbeitung von Beck AT, Steer RA, Brown. (1996). Depressions-Inventory-II (BDI-II). Frankfurt/Main: Pearson 2006. e51. Esser G, Laucht M, Drews S, Ihle W: Depressionstest für Kinder im Grundschulalter. Göttingen: Hogrefe 2013.

e52. Döpfner M, Schnabel M, Goletz H, Ollendick TH: Phobiefragebogen für Kinder und Jugendliche. Göttingen: Hogrefe 2006.

e53. Melfsen S, Florin I, Warnke A: Sozialphobie und -angstinventar für Kinder. Göttingen: Hogrefe 2001.

e54. Görtz-Dorten A, Döpfner M: Fragebogen zum aggressiven Verhalten von Kindern. Göttingen: Hogrefe 2010.

e55. Goletz H, Döpfner M: CY-BOCS, Children's Yale-Brown Obsessive Compulsive Scale. In: Barkmann C, Schulte-Markwort M, Brähler E, (eds.): Klinisch-psychiatrische Ratingskalen für das Kindesund Jugendalter. Göttingen: Hogrefe 2011: 143-8.

e56. Hand I, Büttner-Westphal H: Yale-Brown Obsessive Compulsive Scale (Y-BOCS): Ein halbstrukturiertes Interview zur Beurteilung des Schweregrades von Denk- und Handlungszwängen. Deutsche Übersetzung von Goodman W, Rasmussen S, Price L, Mazurel L, Heninger G, Charney D: Yale-Brown Obsessive Compulsive Scale (Y-BOCS). Verhaltenstherapie 1991; 1: 226-33.

e57. Gönner S, Ecker W, Leonhart R: Obsessive-Compulsive InventoryRevised (dt. Bearbeitung von Foa EB, Huppert JD, Leiberg S, et al.): OCl-R, Obsessive-Compulsive Inventory-Revised). Frankfurt/ Main: Pearson 2009.

e58. Bölte S, Poustka F: Fragebogen zur Sozialen Kommunikation Autismus Screening. Göttingen: Hogrefe 2006

e59. Kamp-Becker I, Mattejat F, Wolf-Ostermann K, Remschmidt H: Die Marburger Beurteilungsskala zum Asperger-Syndrom (MBAS) ein Screening-Verfahren für autistische Störungen auf hohem Funktionsniveau. Z Kinder Jugendpsychiatr Psychother 2005; 33: $15-26$.

e60. Bölte S, Rühl D, Schmötzer G, Poustka F: Diagnostisches Interview für Autismus - Revidiert. Göttingen: Huber 2006.

e61. Poustka L, Rühl D, Feineis-Matthews S, Poustka F, Hartung M, Bölte S: Diagnostische Beobachtungsskala für Autistische Störungen - 2: Göttingen: Hogrefe 2015.

e62. Deutsche Gesellschaft für Kinder- und Jugendpsychiatrie und Psychotherapie (DGKJP): Leitlinien zu Diagnostik und Therapie von psychischen Störungen im Säuglings-, Kindes- und Jugendalter. Köln: Deutscher Ärzte-Verlag 2007.

e63. Döpfner M, Schürmann S, Frölich J: Therapieprogramm für Kinder mit hyperkinetischem und oppositionellem Problemverhalten (THOP). 5 ed. Weinheim: Beltz, Psychologie Verlags Union 2013.

e64. Hoekstra PJ, Buitelaar JK: Is the evidence base of methylphenidate for children and adolescents with attention-deficit/hyperactivity disorder flawed? Eur Child Adolesc Psychiatry 2016; 25: 339-40.

e65. Romanos M, Coghill D, Gerlach M, et al.: Check and double check - the Cochrane review by Storebo et al. (2015) is indeed flawed. Z Kinder Jugendpsychiatr Psychother 2016; 44: 336-7.

e66. Romanos M, Reif A, Banaschewski T: Methylphenidate for attention-deficit/hyperactivity disorder. JAMA 2016; 316: 994-5.

e67. Banaschewski T, Buitelaar J, Coghill D, et al.: Methylphenidate for ADHD in children and adolescents: throwing the baby out with the bathwater. Evid Based Ment Health 2016;19: 97-99.

e68. Büchter RB, Thomas S: Re: Methylphenidate for attention-deficit/ hyperactivity disorder in children and adolescents: Cochrane systematic review with meta-analyses and trial sequential analyses of randomised clinical trials 2016. BMJ 2015; 351: h5203 .

e69. Storebo 0J: Re: Methylphenidate for attention-deficit/hyperactivity disorder in children and adolescents: Cochrane systematic review with meta-analyses and trial sequential analyses of randomised clinical trials. BMJ 2015; 351: h5203.

e70. Hodgkins P, Arnold LE, Shaw M, et al.: A systematic review of global publication trends regarding long-term outcomes of ADHD. Front Psychiatry 2011; 2: 84.

e71. Shaw M, Hodgkins $\mathrm{P}$, Caci $\mathrm{H}$, et al.: A systematic review and analysis of long-term outcomes in attention deficit hyperactivity disorder: effects of treatment and non-treatment. BMC Medicine 2012; 10: 99. 
e72. Shaw P, De Rossi P, Watson B, et al.: Mapping the development of the basal ganglia in children with attention-deficit/hyperactivity disorder. J Am Acad Child Adolesc Psychiatry 2014; 53: 780-9 e11.

e73. Shaw P, Sharp WS, Morrison M, et al.: Psychostimulant treatment and the developing cortex in attention deficit hyperactivity disorder. Am J Psychiatry 2009; 166: 58-63.

e74. Chang Z, Lichtenstein P, Halldner L, et al.: Stimulant ADHD medication and risk for substance abuse. J Child Psychol Psychiatry 2014; 55: 878-85.

e75. Ljung T, Chen Q, Lichtenstein P, Larsson H: Common etiological factors of attention-deficit/hyperactivity disorder and suicidal behavior: a population-based study in Sweden. JAMA Psychiatry 2014; 71: 958-64.

e76. Man KK, Chan EW, Coghill D, et al.: Methylphenidate and the risk of trauma. Pediatrics 2015; 135: 40-8.

e77. Coghill D: The impact of medications on quality of life in attentiondeficit hyperactivity disorder: a systematic review. CNS Drugs 2010; 24: 843-66.

e78. Biederman J, Monuteaux MC, Spencer T, Wilens TE, Faraone SV: Do stimulants protect against psychiatric disorders in youth with ADHD? A 10-year follow-up study. Pediatrics 2009; 124: 71-8.

e79. Uchida M, Spencer TJ, Faraone SV, Biederman J: Adult outcome of ADHD: an overview of results from the MGH Iongitudinal family studies of pediatrically and psychiatrically referred youth with and without ADHD of both sexes. J Atten Disord 2015 (epub ahead of print).

e80. Kooij SJ, Bejerot S, Blackwell A, et al.: European consensus statement on diagnosis and treatment of adult ADHD: The European Network Adult ADHD. BMC Psychiatry 2010; 10: 67. e81. Faraone SV, Buitelaar J: Comparing the efficacy of stimulants for ADHD in children and adolescents using meta-analysis. Eur Child Adolesc Psychiatry 2010; 19: 353-64.

e82. Banaschewski T, Coghill D, Santosh P, et al.: Long-acting medications for the hyperkinetic disorders. A systematic review and European treatment guideline. Eur Child Adolesc Psychiatry 2006; 15: 476-95.

e83. Faraone SV: Understanding the effect size of lisdexamfetamine dimesylate for treating ADHD in children and adults. J Atten Disord 2012; 16: 128-37.

e84. Schwartz S, Correll CU: Efficacy and safety of atomoxetine in children and adolescents with attention-deficit/hyperactivity disorder: results from a comprehensive meta-analysis and metaregression. J Am Acad Child Adolesc Psychiatry 2014; 53: $174-87$.

e85. Hirota T, Schwartz S, Correll CU: Alpha-2 agonists for attentiondeficit/hyperactivity disorder in youth: a systematic review and meta-analysis of monotherapy and add-on trials to stimulant therapy. J Am Acad Child Adolesc Psychiatry 2014; 53 : 153-73.

e86. Newcorn JH, Harpin V, Huss M, et al.: Extended-release guanfacine hydrochloride in 6-17-year olds with ADHD: a randomisedwithdrawal maintenance of efficacy study. J Child Psychol Psychiatry 2016; 57: 717-28.

e87. Christiansen $\mathrm{H}$, Kis B, Hirsch 0 , et al.: German validation of the Conners Adult ADHD Rating Scales (CAARS) II: reliability, validity, diagnostic sensitivity and specificity. Eur Psychiatry 2012; 27: $321-8$ 


\section{eTABLE 1}

Diagnostic instruments

Clinical interviews and diagnosis systems (incl. questionnaires)

\section{Age range}

Reference

- Kiddie-SADS

- Kinder-DIPS

- DISYPS-III (DCL-ADHS, ILF-EXTERNAL, FBB-ADHS, SBB-ADHS)

- HASE

- IDA

\begin{tabular}{|l}
\hline $6-18$ years \\
\hline $6-18$ years \\
\hline From 11 years onward \\
\hline Adults \\
Adults
\end{tabular}

(e44)

(e45)

(e46)

(e47)

(e43)

Further ADHD-specific questionnaires

- Conners 3

- Conners scales for adults

$6-18$ years

$>18$ years

(e87)

Questionnaires on comorbid depression

\begin{tabular}{l|l|l}
\hline- DIKJ & $8-15$ years & (e49) \\
\hline - BDI-II & From 13 years onward & (e50) \\
\hline - DTGA & Preschool and elementary school age & (e51) \\
\hline Questionnaires on comorbid anxiety disorder & \multicolumn{2}{|l}{} \\
\hline - PHOKI & $8-18$ years & (e52) \\
\hline - SPAIK & $8-16$ years & (e53) \\
\hline
\end{tabular}

Questionnaires on comorbid conduct disorder

\begin{tabular}{|c|c|c|}
\hline - FAVK & 9-14 years & (e54) \\
\hline \multicolumn{3}{|c|}{ Questionnaires on comorbid tic disorder } \\
\hline - FBB-TIC / SBB-TIC & Adults/ $11-18$ years & $(\mathrm{e} 46)$ \\
\hline \multicolumn{3}{|c|}{ Questionnaires on comorbid obsessive-compulsive disorder } \\
\hline - CY-BOCS (interview) & $6-17$ years & (e55) \\
\hline - Y-BOCS (interview) & & (e56) \\
\hline$-\mathrm{OCl}$ & Adults & $(\mathrm{e} 57)$ \\
\hline \multicolumn{3}{|c|}{ Questionnaires on comorbid autism spectrum disorder } \\
\hline -FSK & From 4 years onward & (e58) \\
\hline - MBAS & & (e59) \\
\hline$-A D I-R$ & From 2 years onward & $(\mathrm{e} 60)$ \\
\hline- ADOS-2 & From 12 months onward & (e61) \\
\hline
\end{tabular}

